\title{
THE ESTABLISHMENT AND MAINTENANCE OF PREGNANCY
}

\author{
F.W. BAZER, R.D. GEISERT, W.W. THATCHER $†$ and R.M. \\ ROBERTS \\ Departments of Animal Science, Dairy Science $\dagger$, and Biochemistry and \\ Molecular Biology $\ddagger$, University of Florida, USA
}

In many submammalian species considerable energy is expended by the female to produce liver and/or reproductive tract secretions which are incorporated into ova prior to ovulation. Fertilization of these ova may or may not occur. Females of these submammalian species, therefore, expend energy for the reproductive process regardless of whether offspring result.

In mammalian species, such as the pig, restrictions are placed upon the extent to which energy is expended for support of endometrial secretory activity. In the absence of fertilized ova and blastocysts developing in synchrony with the uterine endometrium, the period of endometrial secretory activity is limited primarily to the mid to late luteal phase of the oestrous cycle. In the pig, endometrial secretory activity is dependent upon maintenance of functional corpora lutea (CL). The lifespan of the $\mathrm{CL}$, in turn, is limited during the oestrous cycle by endometrial production of a uterine luteolytic factor which is assumed to be prostaglandin $F_{2 \alpha}\left(\mathrm{PGF}_{2 \alpha}\right)$. Release of $\mathrm{PGF}_{2 \alpha}$ from non-pregnant uterine endometrium results in morphological regression of $\mathrm{CL}$, progesterone secretion ceases and, therefore, progesterone-dependent endometrial secretory activity is terminated in the late luteal phase of the oestrous cycle.

In pigs having normally developing blastocysts, endometrial-blastocyst interactions begin to occur by day 11 of pregnancy. Blastocysts signal their presence, presumably through oestrogen production, which results in CL maintenance and continued endometrial development and secretory activity. Species, such as the pig, that have central or fusion implantation (Schlafke and Enders, 1975) appear to depend upon endometrial histotroph (Amoroso, 1952) for a major portion of pregnancy.

Endometrial secretions of the pig are assumed to contain both a luteolytic factor $\left(\mathrm{PGF}_{2 \alpha}\right)$ and embryotrophic (histotroph) factors. Blastocysts produce oestrogen which is believed to initiate events which result in $\mathrm{CL}$ maintenance, i.e. oestrogen acts as a luteostatic factor. This chapter will discuss evidence for the theory that oestrogens, of blastocyst origin, allow for continued secretion of $\mathrm{PGF}_{2 \alpha}$ and other components of endometrial histotroph into the uterine lumen, i.e. in an exocrine direction, which prevents their release toward the uterine vascular bed, i.e. in an endocrine direction. This mechanism appears to be essential for the establishment and maintenance of pregnancy in pigs. 


\section{The uterus and corpus luteum maintenance}

Sexually mature female pigs (Sus scrofa domesticus) have recurring oestrous cycles of 18 to 21 days throughout the year. Behavioural oestrus lasts for 24-72 hours and ovulation occurs 36-42 hours after onset of oestrus. Corpora lutea are well formed by day 4 or 5 of the oestrous cycle and progesterone secretions increase from that time to maximum production between days 12 and 14 of the oestrous cycle (Guthrie, Henricks and Handlin, 1972). Luteal regression begins on about day 15 in non-pregnant females and plasma progesterone concentrations decline rapidly to basal levels ( $1 \mathrm{ng} / \mathrm{ml}$ or less) by days 17 to 18 , leading to recurrent oestrous cycles unless interrupted by pregnancy or events leading to endocrine dysfunction.

The pig uterine endometrium has been identified as the source of a substance (uterine luteolysin) which causes morphological regression of $\mathrm{CL}$ and cessation of progesterone secretion. Loeb (1923) first noted that hysterectomy of guinea pigs during the luteal phase of the oestrous cycle allowed prolonged $\mathrm{CL}$ maintenance. This was later demonstrated in pigs by Spies et al. (1958) and du Mesnil du Buisson and Dauzier (1959). Anderson, Butcher and Melampy (1961) found that bilateral hysterectomy in the early to mid luteal phase of the oestrous cycle resulted in CL maintenance for periods equal to or longer than the 114 days of a normal pregnancy. Introduction of corrosive and toxic agents into the uterine lumen resulting in destruction of the endometrial epithelium or congenital absence of the uterine endometrium leads to prolonged $\mathrm{CL}$ maintenance (see review by Anderson, Bland and Melampy, 1969).

The nature of the pig uterine endometrial luteolysin has been and is subject to some controversy. Schomberg (1967) initially reported that a high molecular weight component of pig uterine flushings had a luteolytic effect on cultured granulosa cells, but this effect was later shown to be due to a cytolytic factor (Schomberg, 1969).

Pharriss and Wyngarden (1969) reported that $\mathrm{PGF}_{2 \alpha}$ was luteolytic in rats and, subsequently, it was evaluated as a luteolytic agent in swine. Diehl and Day (1973) found 2-5 mg PGF P $_{2 \alpha}$ to be ineffective in shortening the oestrous cycle when administered intraluminally on day 10 or intramuscularly on day 12 of the cycle. Hallford et al. (1974) injected gilts intramuscularly with $20 \mathrm{mg} \mathrm{PGF}_{2 \alpha}$ at 12 hour intervals on days 4 and 5 of the cycle (total dose of $80 \mathrm{mg} \mathrm{PGF}_{2 \alpha}$ ) with no effect on oestrous cycle length. However, when the same $\mathrm{PGF}_{2 \alpha}$ treatment protocol was used on days 12 and 13 , oestrous cycle length was reduced in treated (17.2 days) versus control (18.6 days) gilts. Douglas and Ginther (1975) reported that intramuscular injections of 10 or $20 \mathrm{mg} \mathrm{PGF}_{2 \alpha}$ on day 12 of the oestrous cycle resulted in reduced $\mathrm{CL}$ weight, but neither oestrus nor ovulation had occurred by day 16 of the cycle. In contrast to these results, Diehl and Day (1974) determined that an intramuscular injection of $5 \mathrm{mg} \mathrm{PGF}_{2 \alpha}$ in early pregnant (days 25-30) gilts resulted in a marked decline in plasma progesterone concentrations within 12 hours, followed by abortion and expression of behavioural oestrus within 72 hours.

At this point, it seems necessary to digress from the discussion of $\mathrm{PGF}_{2 \alpha}$ 
so that results presented in previous and subsequent paragraphs can be considered relative to previous work by du Mesnil du Buisson and Leglise (1963). They reported that CL development in pigs hypophysectomized on the first day of oestrus was apparently normal up to day 12 of the oestrous cycle, but $C L$ were undergoing regression by day 16 . It was concluded that pig $C L$ require only initial pituitary support, at or about the time of onset of oestrus, for formation and function for the first 12 days of the oestrous cycle. Later studies indicated that $\mathrm{CL}$ maintenance could be extended beyond day 12 in hysterectomized pigs which were later hypophysectomized and given either bovine luteinizing hormone ( $\mathrm{LH}, 5 \mathrm{mg} / \mathrm{day}$ ), human chorionic gonadotrophin (1000 iu/day) or $250 \mathrm{mg} /$ day of an acid-acetone extract of ovine pituitary (du Mesnil du Buisson and Leglise, 1963; du Mesnil du Buisson, 1966; Anderson et al., 1965). The gonadotrophin preparations were not effective in gilts which had intact uteri which indicated that the uterine luteolytic factor could 'override' pituitary gonadotrophins after day 12 of the oestrous cycle.

Since pig CL appear to be 'autonomous' for the first 12 days of the oestrous cycle, failure of exogenous $\mathrm{PGF}_{2 \alpha}$ to exert a marked effect on oestrous cycle length may be due to refractoriness of $\mathrm{CL}$ until day 12 . If so, pig CL only become susceptible to exogenous $\mathrm{PGF}_{2 \alpha}$ at about the time they would normally regress and the only effect of exogenous $\mathrm{PGF}_{2 \alpha}$ would be a slight reduction in length of the oestrous cycle. This conclusion is supported by results of Diehl and Day (1973), Hallford et al. (1974) and Douglas and Ginther (1975), which were discussed previously. Several other studies, as discussed later (p.231), also support this conclusion.

Caldwell et al. (1969) reported that CL induced with human chorionic gonadotrophin on days $6,8,10$ and 16 of the oestrous cycle remained functional for an average of $12.5,14.5,15.0$ and 19.3 days, respectively, from the day they were induced. Therefore, only CL induced on day 6 were old enough to undergo regression at about the same time as the natural CL. Moeljono, Bazer and Thatcher (1976) treated hysterectomized gilts with intramuscular $\mathrm{PGF}_{2 \alpha}(10 \mathrm{mg}$ at 08.00 hours and $10 \mathrm{mg}$ at 20.00 hours) on either day $8,11,14$ or 17 after onset of oestrus. None of the six gilts treated on either day 8 or day 11 exhibited oestrus for at least 60 days thereafter. Two of three gilts treated on day 14 and all three of the gilts treated on day 17 exhibited oestrus at $116.0 \pm 9.8$ hours ( $\bar{x} \pm$ S.E.M.) post-treatment. Krzymowski et al. (1976) infused a total of $2 \mathrm{mg}$ of $\mathrm{PGF}_{2 \alpha}$ into the anterior uterine vein of sows over a 10 hour period on either day 6 , $8,10,12,14$ or 15 of the oestrous cycle. The $\mathrm{PGF}_{2 \alpha}$ had no effect on CL weight or plasma progesterone concentrations when given on days 6,8 .or 10 , but luteolysis was initiated in sows treated on either day 12,14 or 15 . These data clearly support the concept that pig CL are refractory to the luteolytic effect of $\mathrm{PGF}_{2 \alpha}$ up to day 12 of the oestrous cycle. Henderson and McNatty (1975) suggested that pig $\mathrm{CL}$ may remain refractory to $\mathrm{PGF}_{2 \alpha}$ until $\mathrm{LH}$ begins to dissociate from luteal cell membrane receptors. At this time, presumably on day 12 , conformational changes within the luteal cell membrane may facilitate $\mathrm{PGF}_{2 \alpha}$ binding. The $\mathrm{PGF}_{2 \alpha}$, in turn, is then proposed to alter the adenyl cyclase system to inhibit progesterone secretion and activate lysosomal enzymes to cause morphological regression of the luteal cells. 
Moeljono, Bazer and Thatcher (1976) administered PGF $_{2 \alpha}$ intramuscularly to hysterectomized gilts on either day 17 or 38 post oestrus and reported that all gilts expressed oestrus at an average of $88.0 \pm 13.5$ hours $(\bar{x} \pm$ S.E.M. $)$ after treatment. Saline treated controls did not exhibit oestrus for at least 60 days post treatment. In a subsequent experiment, two gilts were bilaterally hysterectomized and the saphenous artery catheterized on day 7 after the onset of oestrus. On day 17 they received $P F_{2 \alpha}(10 \mathrm{mg}$. intramuscularly at 08.00 hours and $10 \mathrm{mg}$ at 20.00 hours). Plasma progesterone concentrations decreased precipitously after the first injection and gilts exhibited oestrus between 90 and 110 hours after the first PGF $_{2 \alpha}$ injection. An additional gilt was bilaterally hysterectomized and the $\mathrm{CL}$ marked with Indian ink. Treatment with $\mathrm{PGF}_{2 \alpha}$, as before, resulted in oestrus at about 92 hours after the first $\mathrm{PGF}_{2 \alpha}$ injection. On day 4 of the treatment-induced oestrous cycle, regression of $\mathrm{CL}$ to corpora albicantia and presence of newly formed CL were confirmed at laparotomy. These data indicated that $\mathrm{PGF}_{2 \alpha}$ is, by definition, luteolytic in swine, i.e. it causes morphological regression of $\mathrm{CL}$ and cessation of progesterone secretion followed by onset of behavioural oestrus. The luteolytic effect of exogenous $\mathrm{PGF}_{2 \alpha}$ has been demonstrated in hysterectomized gilts (Moeljono, Bazer and Thatcher, 1976), gilts in which CL maintenance has been induced with oestrogen treatment (Kraeling, Barb and Davis, 1975) and pregnant gilts (Diehl and Day, 1974).

Endometrial extracts from days 13 to 17 of the oestrous cycle and day 19 of pregnancy exert a luteolytic effect in unilaterally pregnant gilts having induced CL (Christenson and Day, 1972). Patek and Watson (1976) reported that $P G F$ production in vitro was greater for endometrial tissues from the mid and late luteal phase, compared with tissue obtained earlier in the oestrous cycle, and that this production could be blocked by indomethacin. Watson and Patek (1979) later reported similar conclusions in that in vitro $\mathrm{PGF}_{2 \alpha}$ production was higher for uterine endometrium taken from the late luteal phase of the oestrous cycle than for endometrium obtained during the mid luteal stage of the cycle and early pregnancy (days 16-22). However, $\mathrm{PGF}_{2 \alpha}$ production was similar for endometrium from the mid luteal stage of the oestrous cycle and early pregnancy. Guthrie, Rexroad and Bolt (1978) have also demonstrated in vitro PGF production by pig endometrium representing days $7-8$ and $15-16$ of the oestrous cycle, but they did not detect a difference in PGF production between the two stages. Prostaglandin $F$ is produced in vitro by pig endometrium taken from either day $8,12,14,16$ or 18 of the oestrous cycle (Guthrie and Rexroad, 1980); its production increased from days 8 to 16 and then decreased slightly on day 18 , but only production values for days 16 and 18 were significantly greater than those for days 8,12 and 14 .

In support of these in vitro studies, other research has been directed toward determining concentrations of immunoreactive PGF in uteroovarian vein plasma. Gleeson, Thorburn and Cox (1974), Moeljono et al. (1977), Frank et al. (1977) and Killian, Davis and Day (1976) all concluded that utero-ovarian vein plasma PGF concentrations were significantly greater during the period of expected luteolysis in non-pregnant gilts. 
Halton and First (unpublished data) reported that intrauterine infusion of indomethacin (an inhibitor of $\mathrm{PGF}_{2 \alpha}$ synthesis) resulted in a prolonged luteal phase of the oestrous cycle. This effect of indomethacin could be overcome by intramuscular injection of $\mathrm{PGF}_{2 \alpha}$, which indicated that treatment had no effect on $\mathrm{CL}$ sensitivity to the luteolytic effect of exogenous $\mathrm{PGF}_{2 \alpha}$.

Collectively, available data suggest that endometrial production of PGF is greater during the period of expected luteolysis and that exogenous $\mathrm{PGF}_{2 \alpha}$ is luteolytic in gilts by day 12 after onset of oestrus. Controversy on the question of whether or not $\mathrm{PGF}_{2 \alpha}$ is the pig endometrial luteolytic factor continues. Watson and Walker (1977), for example, reported studies of superfusion of pig CL in vitro with either $\mathrm{PGF}_{2 \alpha}$, endometrial extracts or uterine flushings. Because endometrial superfusates from late luteal phase tissue were more effective than $\mathrm{PFG}_{2 \alpha}$ alone, or uterine flushings, in permanently suppressing $C L$ progesterone production, they suggested that some factor other than $\mathrm{PGF}_{2 \alpha}$ or acting in concert with $\mathrm{PGF}_{2 \alpha}$ must be required for luteolysis. Their conclusion is not supported by the fact that $\mathrm{PGF}_{2 \alpha}$ is luteolytic in bilaterally hysterectomized gilts (Moeljono, Bazer and Thatcher, 1976) and that PGF $2 \alpha$ infusion into the anterior uterine vein of gilts is luteolytic from days 12 to 15 of the oestrous cycle (Krzymowski $e t$ al., 1976). Because of the substantial amount of evidence suggesting that $\mathrm{PGF}_{2 \alpha}$ is the uterine luteolysin in pigs, that assumption will be made relative to subsequent discussion this chapter.

\section{THE LUTEOSTATIC EFFECT OF OESTROGENS IN THE PIG}

In pregnant gilts, embryos move from the oviducts and into the uterine horns at about the 4-cell stage, i.e. about 60-72 hours after onset of oestrus. Embryos reach the blastocyst stage by day 5 and emerge from the zona pellucida (hatching) between days 6 and 7. Blastocysts expand from about $0.5-1 \mathrm{~mm}$ diameter at hatching, to $2-6 \mathrm{~mm}$ diameter on day 10 and then elongate rapidly to a threadlike organism $700-1000 \mathrm{~mm}$ in length by days 14-16 of pregnancy (Perry and Rowlands, 1962; Anderson, 1978). These long filamentous blastocysts lie end to end after initial elongation and follow the contour of the endometrial folds along the entire length of the uterine horns. In order for maintenance of apposition between blastocysts and uterine endometrium, it seems likely that the uterine endometrium and blastocysts grow in a parallel manner between days 10.5 to 11 and 14 to 16 of pregnancy. Perry and Rowlands (1962) reported that the average length of each uterine horn was $360 \mathrm{~cm}$ for gilts on days 13-18 of pregnancy as compared to $190 \mathrm{~cm}$ on day 3 .

Rapid expansion and development of the embryo, and its associated membranes and fluids occurs between days 18 and 30 of gestation and by day 60 placental development is complete. This period of pregnancy will not be discussed.

Several investigators have suggested that the porcine conceptus is the source of oestrogens during gestation (Velle, 1960; Raeside, 1963; Molokwu and Wagner, 1973; Choong and Raeside, 1974; Robertson and King, 1974; Wettemann et al., 1977; Knight et al., 1977). However, Perry, Heap 


\section{The establishment and maintenance of pregnancy}

and Amoroso (1973) first demonstrated conversion of tritium $\left({ }^{3} \mathrm{H}\right)$-labelled dehydroepiandrosterone (DHEA), androstenedione, progesterone and oestrone sulphate to unconjugated oestradiol and oestrone by pig blastocysts. These findings have been extended and confirmed by Heap and Perry (1974), Perry et al. (1976), Flint et al. (1979), Heap et al. (1979) and Gadsby, Heap and Burton (1980).

Evidence for conversion of acetate, cholesterol, progesterone, DHEA, androstenedione and conjugated oestrogens by the conceptus to unconjugated oestrone and oestradiol is also available (Heap et al., 1979). These precursors may be derived, in part, from the maternal circulation; however, conversion of progesterone to androgens and conjugated oestrogens by the uterine endometrium may also serve to provide pig blastocysts with precursors for conversion to free oestrogens. Data from our laboratory indicate that the endometrium from pigs can convert tritium-labelled progesterone to androstenedione, testosterone, oestrone, oestradiol and " conjugated oestrone and oestradiol (Dueben et al., 1977; Dueben et al., 1979; Fischer and Bazer, unpublished data). In addition, Henricks and Tindall (1971) have reported metabolism of ${ }^{3} \mathrm{H}$-progesterone by pig endometrium to at least ten metabolites, of which two have been identified as $5 \alpha$-dihydroprogesterone and its $3 \beta$-hydroxylated counterpart. Henricks and Tindall (1971) and Dueben et al. (1979) found about one third of the radioactivity in the aqueous fraction of homogenized endometrial tissue incubated after three extractions with diethyl ether, which suggests that steroid sulphates and glucuronides are also major products of the endometrial metabolism of ${ }^{3} \mathrm{H}$-progesterone.

The possibility that the uterine endometrium of pregnant gilts metabolizes progesterone is suggested by two lines of evidence. First, Knight $e t$ al. (1977) observed that uterine artery-uterine vein (A-V) differences in plasma progesterone concentrations were positive at all stages of gestation studied between days 20 and 100 . Conversely, A-V differences in oestrone and oestradiol were negative at all stages of gestation studied. These data suggest that progesterone is being taken up and/or metabolized by the pregnant uterus and/or its contents. The second line of evidence is from a study in our laboratory in which gilts were bilaterally ovariectomized on day 4 of pregnancy and treated with $25,50,100$ or $200 \mathrm{mg}$ progesterone/day to maintain pregnancy until day 60 of gestation. Gilts, at day 60 , which were pregnant (viable conceptuses were present) had plasma progestin concentrations ranging from $7-26.5 \mathrm{ng} / \mathrm{ml}$. However, gilts for which there was no evidence that pregnancy had been established had plasma progestin concentrations of $163-428 \mathrm{ng} / \mathrm{ml}$. Thus, events associated with establishment of pregnancy have a marked effect on progesterone metabolism by the uterus and/or conceptuses.

iy In normal pregnancy in pigs there is a $30-70 \%$ decrease in maternal plasma progestin concentrations between days 14 and 30 of gestation (Guthrie, Henricks and Handlin, 1972; Robertson and King, 1974; Moeljono et al., 1977). This decrease in plasma progestin concentrations has been attributed to partial CL regression followed by CL 'rescue' during the period of establishment of pregnancy. However, the decrease in plasma progestins may reflect initiation of progesterone metabolism by the pregnant uterine endometrium and/or conceptuses. 
In considering products of endometrial progesterone metabolism, those products which can be most efficiently converted to free oestrogens may be most important. The percentage conversion of conjugated oestrogens, e.g. oestrone sulphate to oestrone $(82 \%)$ and oestradiol $(16 \%)$ by pig blastocysts is very efficient compared with their conversion of androstenedione to oestrone $(14 \%)$ and oestradiol $(2 \%)$ or their conversion of progesterone to oestrone (2\%) and oestradiol $(0.4 \%)$ (Perry, Heap and Amoroso, 1973; Perry et al., 1976). The pig endometrium is known to have $5 \alpha$-reductase enzymatic activity (Henricks and Tindall, 1971) which would result in $5 \alpha$ reduction of progestins and androgens. The $5 \alpha$ reduced steroids cannot be aromatized to oestrogens (Wilson, 1972). Metabolism of progesterone or other potential oestrogen precursors to conjugated oestrogens by the uterine endometrium would circumvent the need for oestrogen precursor pools of androgens which could be reduced and rendered nonaromatizable and also provide the most efficient form of precursor for 'free' oestrogen production by pig blastocysts. Heap and Perry (1974) have demonstrated aromatase and sulphatase enzymatic activity in blastocyst tissues.

Heap and Perry (1974) have suggested that oestrone and oestradiol are produced by pig blastocysts and that these 'free' oestrogens are acted upon by $17 \beta$-hydroxysteroid dehydrogenase and sulphotransferase in the uterine endometrium as these oestrogens move towards the maternal circulation. Therefore, oestrone sulphate is the primary oestrogen in maternal plasma (Robertson and King, 1974) and allantoic fluid (Dueben et al., 1979). This concept explains the high unconjugated oestrogen concentration acting locally at the interface between blastocyst and endometrium with no systemic effects due to high concentrations of 'free' oestrogens. The 'free' oestrogens may act on the uterus to bring about increased uterine blood flow (Ford and Christenson, 1979), water and electrolyte movement (Goldstein, Bazer and Barron, 1980), maternal recognition of pregnancy phenomena (Bazer and Thatcher, 1977), uterine secretory activity (Roberts and Bazer, 1980) and other events associated with placentation. After exerting their local effect, but before leaving the uterus, the unconjugated oestrogens are conjugated and enter the maternal circulation/h in a biologically inactive form.

Robertson and King (1974) have reported that oestrone sulphate is detectable in peripheral maternal plasma by day 16 of pregnancy $(60 \mathrm{pg} / \mathrm{ml})$ and concentrations increase up to days $23-30(3 \mathrm{ng} / \mathrm{ml}$ at peak). However, they could not detect unconjugated oestrogens in peripheral plasma until days $70-80$ of gestation. In our laboratory, Moeljono et al. (1977) detected greater concentrations of oestradiol $(20 \mathrm{pg} / \mathrm{ml})$ in utero-ovarian vein plasma of pregnant gilts between days 12 and 17 than in utero-ovarian vein plasma of non-pregnant gilts $(5 \mathrm{pg} / \mathrm{ml})$ for the same days of the oestrous cycle. Considerable variability in oestradiol and oestrone utero-ovarian vein plasma concentrations was detected in pregnant pigs during this period. Oestradiol concentrations of $240 \mathrm{pg} / \mathrm{ml}$ were detected, but duration and day of occurrence varied considerably. Oestrone concentrations were of lower magnitude.

Total recoverable oestrone and oestradiol in uterine flushings obtained on days $6,8,10,12,14,15,16$ and 18 of the oestrous cycle and pregnancy 
have been reported by Zavy et al. (1980). Both total recoverable oestrone and oestradiol were greater in uterine flushings from pregnant gilts from days 12-18, which supports the concept that pig blastocysts begin to produce oestrogen by day 12 (Perry et al., 1976).

At this point, it is necessary to discuss oestrogen production by pig blastocysts during critical stages of pig blastocyst elongation. Anderson (1978) reported that pig blastocysts were spherical on days $9(0.8 \mathrm{~mm}$ diameter) and 10 (2.9 mm diameter), achieved a tubular form on day 11 ( $58 \mathrm{~mm}$ long) and then elongated to the filamentous form by day 12 (100 mm long). Pig blastocysts in this study reached a maximum length of $700-900 \mathrm{~mm}$ between days 14 and 16 of pregnancy. The rate of change in blastocyst development during this period is highly variable and extremely rapid during the transition from tubular to filamentous form. Geisert and Bazer (unpublished data) estimated that the increase in diameter of spherical blastocysts was at a rate of $0.3-0.4 \mathrm{~mm} /$ hour between the $2.5 \mathrm{~mm}$ diameter and $10 \mathrm{~mm}$ diameter stage. However, once blastocysts reached the tubular form of $10-50 \mathrm{~mm}$ length, they elongated rapidly at rates of up to $45 \mathrm{~mm} /$ hour. This estimate was based on recovery of blastocysts from one uterine horn of a gilt on day 11 that had an average length of $51 \mathrm{~mm}$. Two hours later the other uterine horn was found to contain blastocysts with an average length of $141 \mathrm{~mm}$. In another gilt, blastocysts changed from $11 \mathrm{~mm}$ in diameter to greater than $150 \mathrm{~mm}$ in length within 6 hours, for a rate of change of at least $20-25 \mathrm{~mm} / \mathrm{hour}$. The transition period from large spherical blastocysts to the filamentous form represents the time that close apposition is achieved between blastocysts and endometrium (Crombie, 1972) and oestrogen production begins (Geisert, Bazer and Thatcher, unpublished data; Heap et al., 1979).

In order to closely examine the relationship between stage of blastocyst development and oestrogen production, uterine flushings were obtained from pregnant and non-pregnant gilts between days 10.5 and 12 after onset of oestrus. Uterine flushings were obtained from one uterine horn from all females on day 10.5 and the second uterine horn was flushed later on either day $11,11.5$ or 12 of the oestrous cycle. Variability in blastocyst development among gilts over this 36 hour period was great, as has been noted by Anderson (1978). For example, filamentous blastocysts were recovered from one gilt on day 10.5 while all other gilts had blastocysts of less than $10 \mathrm{~mm}$ diameter. On day 12, most gilts had filamentous blastocysts, but some gilts had blastocysts which were still in the èarly tubular stage. In examining the data, it was obvious that total recoverable oestrogens in uterine flushings were closely associated with stage of blastocyst development rather than the actual day on which the uterine flushing was obtained. The data in Table 12.1 are, therefore, organized and summarized relative to the stage of blastocyst development.

Total recoverable oestrone $\left(E_{1}\right)$, oestradiol $\left(E_{2}\right)$, oestriol $\left(E_{3}\right)$, oestrone sulphate $\left(E_{1} S\right)$, oestradiol sulphate $\left(E_{2} S\right)$ and oestriol sulphate $\left(E_{3} S\right)$ were measured in uterine flushings from pregnant and non-pregnant pigs. Total recoverable $E_{1}$ and $E_{2}$ were greater in flushings having tubular and filamentous blastocysts, but an increase in $E_{3}$ was not apparent except in uterine flushings containing filamentous blastocysts. Total recoverable $E_{1} S$ and $E_{2} S$ also were greater in uterine flushings containing tubular and 


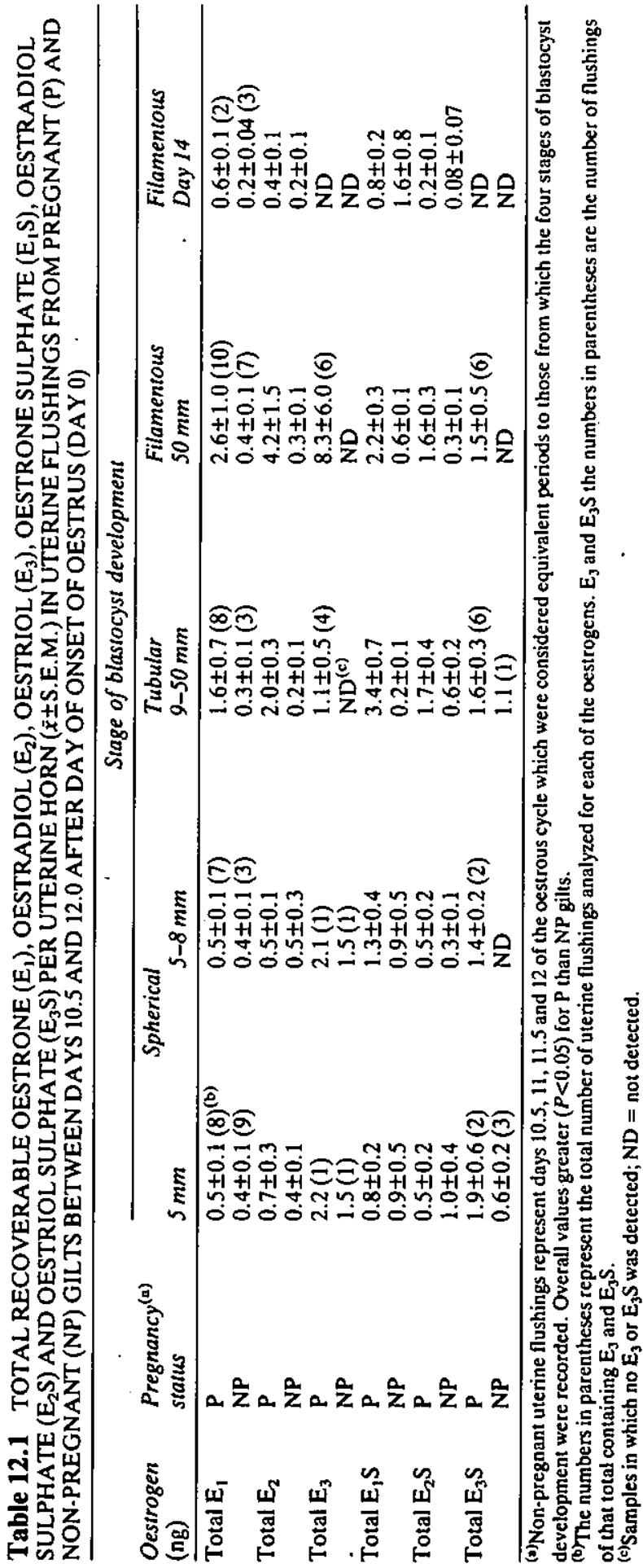


filamentous blastocysts. However, total recoverable $\mathrm{E}_{3} \mathrm{~S}$ was greater for uterine flushings containing tubular (6 of 8 ) and filamentous (6 of 10) blastocysts compared with flushings containing spherical (4 of 15) blastocysts.

There was no discernible trend for total recoverable $E_{1}, E_{2}, E_{3}, E_{2} S$ or $E_{3} S$ in uterine flushings from days $10.5,11,11.5$ and 12 of the oestrous cycle. The $E_{1} S$ did, however, tend to be present in less quantity in uterine flushings from days 11.5 and 12 of the oestrous cycle. That $E_{1} S, E_{2} S$ and, in a few cases, $E_{3} S$ are present in uterine flushings from non-pregnant animals supports the possibility of their serving as readily available precursors for conversion to 'free' $E_{1}, E_{2}$ and $E_{3}$ by potential blastocysts.

It should be noted that total recoverable $E_{2}$ is greater than $E_{1}$, and $E_{3}$ is greater than $E_{1}$ and $E_{2}$ in uterine flushings containing filamentous blastocysts. Zavy et al. (1980) also found total recoverable $\mathrm{E}_{2}$ to be greater than $E_{1}$ in uterine flushings recovered on days 6,10 and 12 of pregnancy, but total $E_{1}$ was greater than $E_{2}$ in uterine flushings collected on days $14,15,16$ and 18 of gestation.

Observations on total recoverable $E_{1}, E_{2}, E_{3}, E_{1} S, E_{2} S$ and $E_{3} S$ in uterine flushings from day 14 of pregnancy indicate a decrease for all of these oestrogens relative to values found on about day 12 (early filamentous blastocysts). This implies that a transient increase in oestrogen production may accompany the transition from the spherical to early filamentous stages of pig blastocyst development and decline thereafter. This implication is supported by preliminary results from a study of $E_{1} S$ concentrations in utero-ovarian vein plasma of three pregnant gilts. The $\mathrm{E}_{1} \mathrm{~S}$ concentrations ( $\bar{x} \pm$ S.E.M.) were $95.0 \pm 22.8,73.0 \pm 2.2,153.4 \pm 21.5$, $104.0 \pm 9.5,75.3 \pm 16.9$ and $55.8 \pm 12.4 \mathrm{pg} / \mathrm{ml}$ on days $9,10,11,12,13$ and 14 of pregnancy, respectively. For non-pregnant pigs (two gilts) utero-ovarian vein plasma $E_{1} S$ concentrations ( $\bar{x} \pm$ S.E.M.) were $54.2 \pm 11.5,71.8 \pm 10.3,34.4 \pm 6.9,68.6 \pm 21.7,76.9 \pm 12.9$ and $40.0 \pm 9.1 \mathrm{pg} /$ $\mathrm{ml}$ on days $9,10,11,12,13$ and 14 , respectively. For pregnant gilts, therefore, greater $(P<0.05)$ plasma $\mathrm{E}_{1} \mathrm{~S}$ concentrations were detected on days 11 and 12 . This is consistent with data on total recoverable unconjugated and conjugated oestrogens previously described for pregnant uterine flushings.

Assuming that free oestrogens provide the signal for maternal recognition of pregnancy in pigs, the collective data of Heap et al. (1979), Zavy et al. (1980) and Geisert, Bazer, Thatcher and Roberts (unpublished data) suggest that this signal is provided on days 11 and 12 of pregnancy. If unconjugated oestrogens are the porcine conceptus' signal for the maternal recognition of pregnancy, injection of exogenous oestrogens should allow for continued $\mathrm{CL}$ maintenance (luteostasis) and uterine function. Kidder, Casida and Grummer (1955), Gardner, First and Casida (1963), Chakraborty, England and Stormshak (1972), Frank et al. (1977) and Frank et al. (1978) have demonstrated that injection of oestrogen into gilts on or before day 11 of the oestrous cycle results in luteal maintenance. Anderson et al. (1965) have reported that daily injections of LH (5 mg/day) results in luteal maintenance in hypophysectomized sows only if the uterus is removed or if LH and oestrogen are administered concurrently. Du Mesnil du Buisson (1966) examined the effect of oestrogen in non-pregnant, hypophysectomized gilts in which the uterus was intact. Injection of $5 \mathrm{mg}$ oestradiol 
valerate $\left(E_{2} \mathrm{~V}\right)$ and $5 \mathrm{mg} \mathrm{LH}$ daily from days 12-20 allowed maintenance of $\mathrm{CL}$ of normal size. He concluded that, since the pituitary was absent, oestrogen was not acting by modifying a gonadotrophic factor, but was inhibiting the luteolytic action of the uterus by blocking secretion or excretion of the uterine luteolysin.

In our laboratory, the term pseudopregnant gilt is used to refer to females that have received $5 \mathrm{mg} \mathrm{E}_{2} \mathrm{~V}$ daily from days $11-15$ of the oestrous cycle. These gilts have interoestrous intervals ranging from 50 to over 300 days, but mean ( $\bar{x} \pm$ S.E.M.) interoestrous intervals were $146.5 \pm 74.8$ days (Frank et al., 1977) and 92 \pm 11.2 days (Frank et al., 1978) in two studies. Termination of pseudopregnancy is often preceded by swelling of the vulva and engorgement of mammary glands from which milk can be expressed (Frank and Bazer, unpublished data).

Progesterone $\left(\mathrm{P}_{4}\right)$ and $\mathrm{E}_{1} \mathrm{~S}$ concentrations in jugular vein plasma have been determined for five gilts'at selected intervals between days 10 and 110 of pseudopregnancy and compared with values from contemporary pregnant gilts having either 4 to 7 (three gilts) or 8 to 11 (three gilts) foetuses at day 110 of pregnancy (Kensinger, Bazer and Collier, unpublished data). Plasma $\mathrm{P}_{4}$ concentrations were not significantly different between the pseudopregnant and pregnant gilts. Plasma total conjugated oestrogen concentrations ( $\bar{x} \pm$ S.E.M.) increased from $476 \pm 54 \mathrm{pg} / \mathrm{ml}$ on day 10 to $1727 \pm 721 \mathrm{pg} / \mathrm{ml}$ on day 30 of pseudopregnancy and then declined to concentrations of $420 \pm 92$ to $1249 \pm 492 \mathrm{pg} / \mathrm{ml}$ on days 40 and 110 , respectively. Data for plasma progesterone and total conjugated oestrogen concentrations are depicted in Figure 12.1. The pseudopregnant and pregnant gilts had similar patterns of change in plasma $E_{1} S$ between days 10 and 70 after onset of oestrus, but $E_{1} S$ did not increase in pseudopregnant gilts between days 70 and 110 as was the case for pregnant gilts.

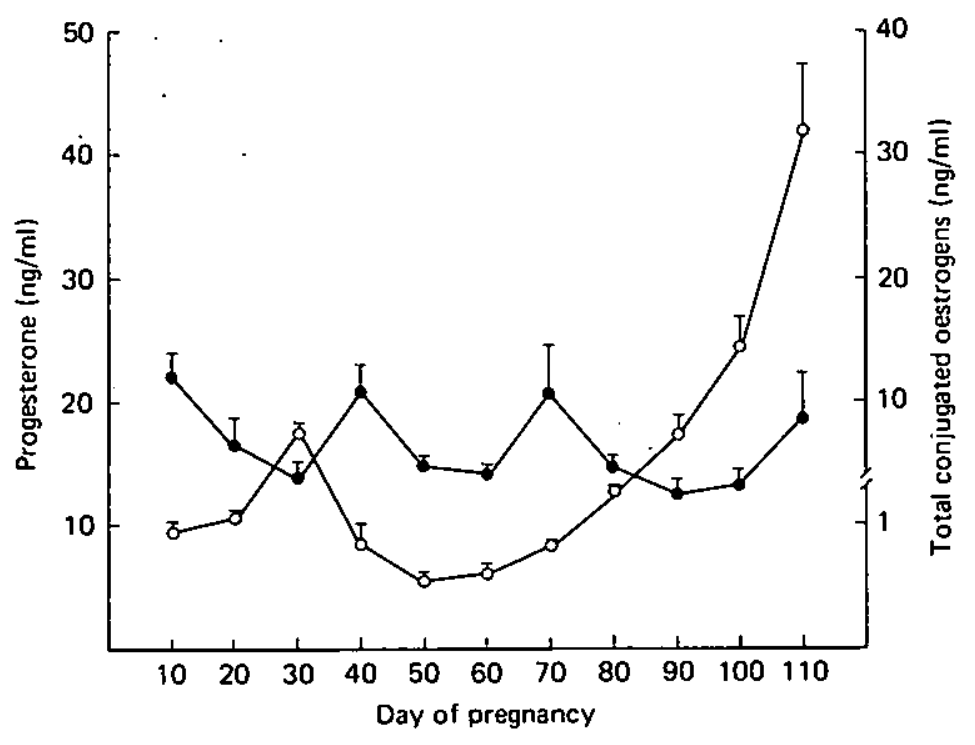

Figure 12.1 Concentrations of progesterone (-) and total conjugated oestrogens $(\mathrm{O}-\mathrm{O})$ in peripheral plasma of gilts between days 10 and 110 of pregnancy. 
Furthermore, $E_{1} S$ concentrations for pseudopregnant gilts were much lower $(P<0.01)$ than those for pregnant gilts.

Uterine endometrial function, based on quantitative and qualitative aspects of proteins secreted into the uterine lumen (Basha et al., 1980) or by endometrial explants in vitro (Basha, Bazer and Roberts, 1980), appears to be identical for pregnant and pseudopregnant pigs on days 60-75 after onset of oestrus. Inhibition of uteroferrin secretion by the pregnant uterine endometrium occurs as placental oestrogen production increases between day 70 of gestation and term (Basha, Bazer and Roberts, 1979). This oestrogen-associated inhibition does not occur in pseudopregnant gilts which have an accumulation of uteroferrin within the uterine lumen from days 45-110 (Bazer, Kensinger, Collier and Roberts, unpublished data).

PROSTAGLANDIN F IN NON-PREGNANT VERSUS PREGNANT AND PSEUDOPREGNANT GILTS

Prostaglandin $F_{2 \alpha}$ has been shown to exert a luteolytic effect on pig.CL by about day 12 after onset of oestrus, as previously discussed (p.229). The studies described in this section were designed to examine the relationship between utero-ovarian vein concentrations of immunoreactive prostaglan$\operatorname{din} \mathrm{F}$ (PGF) and CL function during the oestrous cycle and the first three to four weeks of either pregnancy or pseudopregnancy.

Gleeson, Thorburn and Cox (1974) first reported a temporal relationship between elevated PGF concentrations in utero-ovarian vein plasma of pigs and declining plasma progesterone concentrations associated with CL regression. Moeljono et al. (1977) later compared uteroovarian vein plasma PGF and peripheral plasma progestins in nonpregnant and pregnant pigs. Utero-ovarian vein samples were collected at 15 minute intervals between 07.00 and 10.00 hours, and 19.00 and 22.00 hours each day from day 12 until either onset of oestrus or day 25 of pregnancy. Utero-ovarian vein PGF concentrations were significantly elevated $(P<0.01)$ between days 13 and 17 of the oestrous cycle when plasma progestin concentrations were declining rapidly (Figure 12.2). For pregnant gilts however, there were no significant changes in utero-ovarian vein PGF concentrations between days 12 and 25 of pregnancy (Figure 12.3). When compared to data from pregnant gilts, utero-ovarian vein mean PGF concentrations, the number of PGF peaks (concentrations greater than $\bar{x} \pm 2 S$.D. for each gilt) and the frequency of PGF peaks were greater for non-pregnant gilts.

Killian, Davis and Day (1976) reported comparison of utero-ovarian vein plasma concentrations of PGF and progesterone between days 10 and 18 of the oestrous cycle and pregnancy. Blood samples were collected three times daily between 08.00 and 24.00 hours from six non-pregnant and six pregnant gilts. For non-pregnant gilts, mean plasma PGF concentrations varied significantly $(P<0.02)$ among days and increased from $0.26 \mathrm{ng} / \mathrm{ml}$ on day 10 to $1.48 \mathrm{ng} / \mathrm{ml}$ on day 16 and then declined to $0.61 \mathrm{ng} / \mathrm{ml}$ on day 18 . A correlation coefficient of $-0.96(P<0.01)$ was reported for the temporal relationship between plasma progesterone and PGF concentrations in 


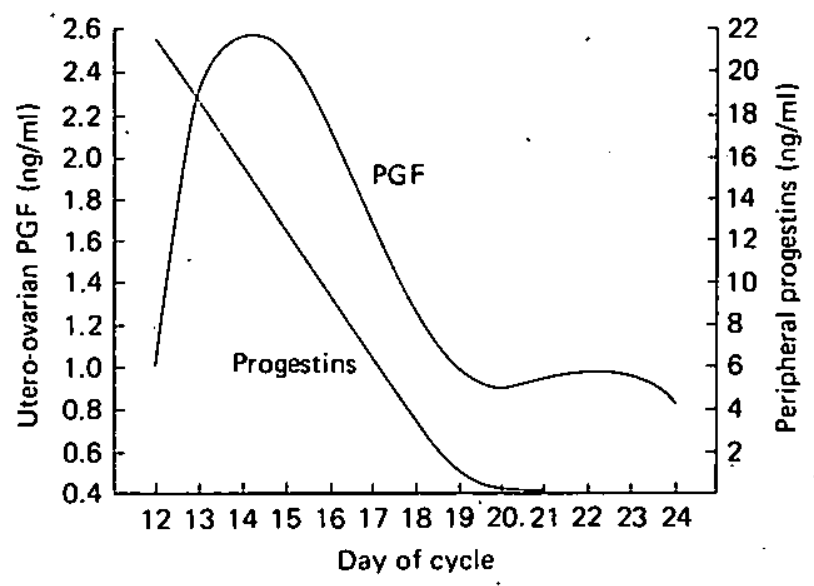

Figure 12.2 The temporal relationship between increasing concentrations of PGF in utero-ovarian vein plasma and decreasing concentrations of progesterone in peripheral plasma in non-pregnant gilts suggest that PGF, of uterine endometrial origin, is involved in luteolysis

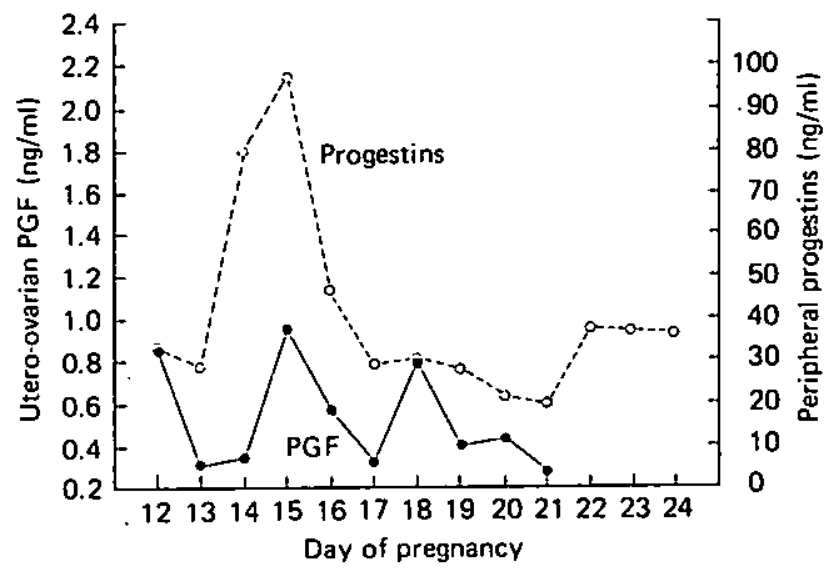

Figure 12.3 The concentrations of PGF in utero-ovarian vein plasma of pregnant gilts do not change significantly between days 12 and 24 of gestation and corpora lutea are maintained as indicated by progesterone concentrations in peripheral plasma.

non-pregnant gilts. For pregnant gilts, plasma PGF concentrations were not significantly affected by day of pregnancy and varied only between 0.42 and $0.78 \mathrm{ng} / \mathrm{ml}$. A non-significant correlation coefficient of only 0.02 was found between plasma progesterone and PGF concentrations in pregnant gilts.

Collectively, the data of Gleeson, Thorburn and Cox (1974), Killian, Davis and Day (1976), Moeljono et al. (1977) and Frank et al. (1977) clearly indicate a strong temporal relationship between elevated uteroovarian vein plasma PGF concentrations and decreasing plasma progesterone concentrations associated with luteolysis. However, plasma progesterone and PGF were not related in pregnant gilts (Killian, Davis and Day, 1976; Moeljono et al., 1977). 
Subsequent to the reports of Killian, Davis and Day (1976) and Moeljono et al. (1977), Ford and Christenson (1979) observed that uterine arterial blood flow increases 2- to 4-fold from day $11(50 \mathrm{ml} / \mathrm{min})$ to days 12 and $13(150-200 \mathrm{ml} / \mathrm{min})$ of pregnancy. By day 14 of pregnancy, uterine blood flow decreases slightly to $100-150 \mathrm{ml} / \mathrm{min}$ but remains higher than for comparable days of the oestrous cycle. These data raise the question of whether or not utero-ovarian vein concentrations are lower between days 12 and 16 of pregnancy because of the dilution effect of increased uterine blood flow. Data are not available which compare rate of release of PGF from the pregnant and non-pregnant uterus. However, results of studies of the PGF metabolite 13,14-dihydro-15-keto- PGF $_{2}$ (PGFM) in peripheral plasma of non-pregnant and pregnant gilts have been reported (Shille et al., 1979; Terqui, Martinat-Botte and Thatcher, 1979). In both studies, samples were obtained from peripheral veins and PGFM concentrations reflect sampling from a plasma pool that should not be affected by changes in uterine blood flow. Data from both studies support the conclusions of Killian, Davis and Day (1976) and Moeljono et al. (1977) that there is greater PGF release from the uterus during the period of luteal regression. PGFM concentrations were elevated between days 12 or 13 and days 15 to 17 of the oestrous cycle. However, only basal PGFM concentrations $(0.1-0.2 \mathrm{ng} / \mathrm{ml})$ were detected during comparable periods of pregnancy, except for occasional transient increases.

Collectively, these data indicate that there is greater release of PGF into the utero-ovarian vein during the period of luteolysis in non-pregnant pigs. However, release of PGF into the utero-ovarian vein of pregnant pigs remains at a 'basal' level and CL maintenance results.

The results of the previous experiments raise the question of whether or not PGF production by the uterine endometrium is altered during pregnancy. An experiment was designed, therefore, to examine total recoverable PGF in uterine flushings representing days $8,10,12,14,15,16$ and 18 of the oestrous cycle and pregnancy. Total recoverable PGF was greater $(P<0.01)$ in uterine flushings from pregnant gilts than from non-pregnant gilts (Zavy et al., 1980). For non-pregnant gilts, total recoverable PGF ( $\bar{x} \pm$ S.E.M.) of $464.5 \pm 37.6 \mathrm{ng}$ on day 18 was maximum, compared with $22688.1 \pm 1772.4 \mathrm{ng}$ on day 18 of pregnancy. These data indicate that PGF synthesis and secretion is not being inhibited during pregnancy and suggest that PGF of endometrial and/or conceptus origin is sequestered within the uterine lumen of pregnant gilts. Utero-ovarian vein plasma PGF and peripheral vein plasma PGFM concentrations support this interpretation. The PGF produced by the uterus appears to enter the uterine venous drainage during the mid to late luteal phase of the oestrous cycle, but not during early pregnancy. Walker et al. (1977) have suggested that the conceptus (amnion in particular) may be involved in metabolizing $\mathrm{PGF}_{2}$ and $\mathrm{PGE}_{2}$ to their respective PGFM; however, data comparing PGF and PGFM in uterine flushings and utero-ovarian vein plasma of non-pregnant and pregnant pigs are not available.

Since prolonged CL maintenance (pseudopregnancy) can be induced in gilts by administration of $5 \mathrm{mg} \mathrm{E}_{2} \mathrm{~V}$ daily on days $11-15$ of the oestrous cycle, Frank et al. (1977) have studied utero-ovarian vein plasma PGF and peripheral plasma progestin concentrations. The experimental protocol 
was essentially identical to that used by Moeljono et al. (1977) for comparisons between non-pregnant and pregnant gilts. Similar to the results of Moeljono et al. (1977), utero-ovarian vein plasma PGF concentrations were significantly greater between days 12 and 17 than on either days 10 and 11 or 18 of the oestrous cycle for control pigs. Plasma progesterone concentrations decreased rapidly between days 13 and 15 and the average interoestrous interval for the control gilts was $19 \pm 0.6$ $(\tilde{x} \pm$ S.E.M.) days. Mean utero-ovarian vein plasma PGF concentrations, number of PGF peaks (concentrations greater than $\bar{x} \pm 2$ S.D. for each gilt) and frequency of PGF peaks were all significantly lower for $E_{2} V$-treated gilts than for control gilts. The mean interoestrous interval was $146.5 \pm 74.8$ $\left(\bar{x} \pm\right.$ S.E.M.) days for $\mathrm{E}_{2} \mathrm{~V}$-treated gilts.

In a subsequent experiment, Frank et al. (1978) have examined total recoverable PGF in uterine flushings recovered on days $11,13,15,17$ and 19 of the oestrous cycle and $\mathrm{E}_{2} \mathrm{~V}$-induced pseudopregnancy. Total recoverable PGF per uterine horn ( $\tilde{x} \pm$ S.E:M.) was maximal $(210.2 \pm 58.7 \mathrm{ng}$ ) on day 17 of the oestrous cycle. For pseudopregnant gilts, however, there was a linear increase in total recoverable PGF from $1.9 \pm 0.8 \mathrm{ng}$ on day 11 to $5113.3 \pm 1735.1 \mathrm{ng}$ on day 19 . These data indicate that PGF secretion is not inhibited in pseudopregnant pigs. Rather, instead of PGF entering the utero-ovarian venous drainage, as appears to occur in non-pregnant gilts, PGF is sequestered within the uterine lumen as previously discussed for pregnant gilts. It should be noted that total recoverable PGF was only $5113 \mathrm{ng}$ per uterine horn or about $10226 \mathrm{ng}$ for both horns, as compared to $22688 \mathrm{ng}$ from both uterine horns of pregnant gilts. This may reflect some contribution of PGF by pig blastocysts as has been reported for cow blastocysts (Lewis et al., 1979).

\section{UTEROFERRIN}

Uteroferrin is the purple coloured, progesterone-induced, intrauterine glycoprotein of pig uterine secretions (histotroph) which appears to be involved in transport of iron from the uterine endometrium to the porcine conceptus (see review by Roberts and Bazer, 1980). Uteroferrin is synthesized and secreted by the surface and glandular epithelium of the pig uterine endometrium (Chen $e t$ al., 1975). In non-pregnant gilts, uteroferrin is secreted into the lumen of the uterine glands between days 9 and 13 of the oestrous cycle. Beginning on day 14, however, uteroferrin begins to become localized within the uterine endometrial stroma surrounding the basement membrane of uterine glands. It is possible that uteroferrin enters the interstitial fluid and/or vascular system within the endometrial stroma for transport to the spleen or liver for degradation and conservation of the iron. In contrast to the changing pattern of localization of uteroferrin in non-pregnant gilts, uteroferrin has not been found in the endometrial stroma at any of the stages of pregnancy studied, i.e. days $6,8,12,14,16$, $18,30,50,70$ and 90 of gestation. Uteroferrin is always localized within the epithelial cells and lumen of uterine glands and within the placental areolae after day 30 of pregnancy. In the pregnant animal, uteroferrin, one component of uterine histotroph, continues to be secreted into the uterine 
lumen where it is available to provide a nutrient source to the developing pig conceptus for a major portion of gestation. These observations on uteroferrin localization by Chen et al. (1975) have provided the basis for the question of whether or not oestrogens might prevent $\mathrm{CL}$ regression in the pig by affecting the direction of secretion of PGF by the uterine endometrium.

\section{Theory of maternal recognition of pregnancy in the pig}

The theory of maternal recognition of pregnancy in the pig to be discussed is the one proposed by Bazer and Thatcher (1977). In non-pregnant pigs it is proposed that progesterone enhances and/or induces PGF synthesis by the uterine endometrium and secretion is associated with elevated plasma oestradiol concentrations between days 12 and 18 of the oestrous cycle (Zavy et al., 1980). This oestrogen is likely to be of ovarian origin and is not present in adequate concentration in the endometrium to elicit a pseudopregnant response. Secretion of PGF during the mid to late luteal phase of the oestrous cycle is primarily in an endocrine direction, i.e. toward the uterine venous drainage. This is based on the observations that utero-ovarian vein PGF concentrations are greatest between days 12 and 18 of the oestrous cycle when events leading to luteolysis are initiated. It has also been pointed out that there is little PGF accumulation within the uterine lumen during the oestrous cycle.

In pregnant pigs, it is also assumed that progesterone enhances and/or induces PGF synthesis by the uterine endometrium and that secretion is enhanced by markedly elevated oestrogen concentrations due to blastocyst production of oestrogens. However, oestrogens produced by pig blastocysts as early as day 11 (tubular and filamentous blastocysts) of pregnancy, alter the direction of movement of PGF so that its secretion remains in an exocrine direction, i.e. toward the uterine lumen. Maintenance of PGF secretion in an exocrine direction would prevent PGF from entering the uterine venous drainage and exerting a luteolytic effect on the CL. That is, the endocrine role of the endometrium would be negated by the effect(s) of oestrogens produced by the blastocysts. Of comparable significance is the fact that maintenance of histotroph secretion in an exocrine direction is essential for nourishment of the pig conceptus.

The proposed theory requires that mechanisms exist for altering the direction of movement of PGF from the epithelial cells of the uterine endometrium where it is assumed to be produced, and that PGF can be compartmentalized and sequestered when the uterus is under appropriate hormonal stimulation (see Figure 12.4).

Ogra $e t$ al. (1974) used immunofluorescent antibody procedures to localize PGF in the oviductal epithelium of women. PGF was localized in the mucosa during the pre-ovulatory phase of the menstrual cycle, but during the post-ovulatory phase it was localized in the lamina propria. Bito, Wallenstein and Baroody (1976) have suggested that the movement of prostaglandins is carrier-mediated and that they do not necessarily freely penetrate cell membranes. Bito (1972) and Bito and Spellane (1974) have provided evidence for the accumulation of prostaglandins in uterine tissues 


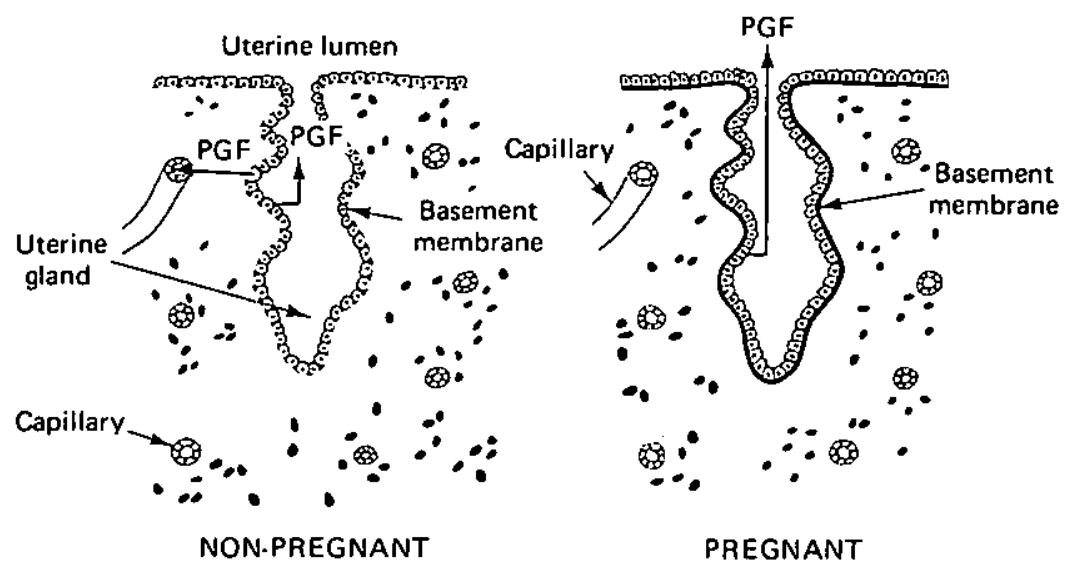

Figure 12.4 In non-pregnant pigs PGF and at least some components of histotroph, e.g. uteroferrin, move toward the endometrial stroma (endocrine direction) during the period of corpora lutea regression. For pregnant pigs, secretion of PGF and histotroph into the uterine lumen (exocrine direction) is maintained. This allows sequestering of the uterine luteolysin as well as histotroph for support of conceptus development

and for the facilitated transport of $\mathrm{PGF}_{2 \alpha}$ from the lumen of the rabbit vagina.

There is abundant evidence that PGF can be compartmentalized and sequestered within reproductive tissues during pregnancy. Data indicating PGF accumulation within the uterine lumen of pregnant (Zavy et al., 1980) and pseudopregnant gilts (Frank et al., 1978) have been discussed. PGF also appears to be sequestered in allantoic fluid of pig conceptuses (Moeljono, Bazer and Thatcher, unpublished data). Based on the assay of PGF in six to eight samples from various days of pregnancy, allantoic PGF content/conceptus (PGF concentration $\times$ allantoic fluid volume/conceptus, $\bar{x} \pm$ S.E.M.) was $0.4 \pm 0.04 \mu \mathrm{g}, 98.4 \pm 4.5 \mu \mathrm{g}, 46.1 \pm 1.9 \mu \mathrm{g}, 76.0 \pm 4.5 \mu \mathrm{g}$ and $8.1 \pm 0.2 \mu \mathrm{g}$ on days $20,35,40,60$ and 100 of gestation, respectively.

Harrison et al. (1972) recovered from $150 \mathrm{ng}$ to $7.6 \mathrm{mg}$ of authentic $\mathrm{PGF}_{2 \alpha}$ (analysis by gas chromatography-mass spectrometry) from fluid within the uterine horn of sheep exhibiting prolonged $\mathrm{CL}$ maintenance after autotransplantation of the ovary to the neck. This finding was later confirmed in pregnant ewes having a surgically prepared uterine pouch. Fluid from the pouches contained 0.1-333 $\mu$ g total PGF ${ }_{2}$ (Harrison, Heap and Poyser, 1976). Bazer et al. (1979) detected 222.8 $668 \mu \mathrm{g}$ PGF in uterine fluid of unilaterally pregnant ewes on day 140 of gestation.

Total recoverable PGF in bovine uterine flushings increased from $13.9 \mathrm{ng}$ on day 8 to $111.0 \mathrm{ng}$ on day 19 of the oestrous cycle and from $17 \mathrm{ng}$ to $1188 \mathrm{ng}$ between days 8 and 19 of pregnancy (Thatcher et al., 1979). Bovine allantoic fluid total PGF was reported to increase from $48.9 \pm 12 \mathrm{ng}$ on day 27 to $4228.9 \pm 177.2 \mathrm{ng}$ on day 111 of pregnancy while total PGF in amniotic fluid increased from $206.9 \pm 109.9 \mathrm{ng}$ on day 60 to $8111.2 \pm 1918.9$ ng on day 111 (Eley, Thatcher and Bazer, 1979).

Data on PGF accumulation have been presented to emphasize the fact that PGF can be sequestered and compartmentalized with the pregnant 
and pseudopregnant uterus. However, data are not available concerning either the mechanism(s) whereby this is accomplished or the hormonal control of such mechanisms.

Bazer and Thatcher (1977) have suggested that the luteostatic effect of oestrogens of blastocyst origin or of exogenous oestrogen is on the uterine endometrium. This concept is based on the following evidence:

(a) it is well established that simple removal of the uterus from otherwise intact gilts, without hormonal therapy, allows for prolonged CL maintenance;

(b) $\mathrm{CL}$ of pregnant gilts and pseudopregnant gilts are susceptible to the luteolytic effect of exogenous $\mathrm{PGF}_{2 \alpha}$;

(c) production of $\mathrm{PGF}_{2 \alpha}$ by endometrium from pregnant and pseudopregnant gilts is not inhibited and appears to be equal to that for mid-luteal phase endometrium of non-pregnant gilts;

(d) LaMotte (1977) has concluded that $\mathrm{PGF}_{2 \alpha}$ is secreted into the uterine lumen and transferred from there to the uterine venous circulation in non-pregnant gilts;

(e) the production of a systemic luteostatic factor seems unlikely since establishment of pregnancy in only one uterine horn does not have a protective effect on the CL of both ovaries.

\section{POTENTIAL ROLES FOR PGF IN THE PREGNANT UTERUS}

Prostaglandins elicit an array of biochemical, physiological and endocrinological effects on various cellular processes and hormonal secretions (Thatcher and Chenault, 1976). Of particular significance in the establishment of pregnancy are the effects of prostaglandins on:

(a) blood flow mediated through changes in the vasodilation of arterioles and the capillary bed (Janson, Albrecht and Ahren, 1975);

(b) changes in the permeability of the endometrial vascular bed (Kennedy, 1980);

(c) fluid and electrolyte transport across epithelia (Heintze et al., 1975; Barry, Hall and Martin, 1975; Biggers et al., 1978);

(d) cellular proliferation as mediated through cyclic-AMP (MacManus and Whitfield, 1974) and steroid biosynthesis (Batta, 1975).

With respect to the effect of PGF on steroid biosynthesis, data from our laboratory have indicated that $\mathrm{PGF}_{2 \alpha}(75 \mathrm{ng} / \mathrm{ml}$ medium $)$ tends to increase $(P<0.05)$ secretion of oestradiol by day 20 pig conceptuses incubated for 4 hours in vitro (Valdivia, Bazer and Thatcher, unpublished data).

Although evidence for these various effects of prostaglandins have been documented in other species, data are not available to indicate their specific role(s) within the pregnant uterus of pigs.

\section{CHANGES IN SELECTED COMPONENTS OF UTERINE SECRETIONS DURING ESTABLISHMENT OF PREGNANCY}

Uterine flushings obtained, as previously described, to obtain data on unconjugated and conjugated oestrogens (Table 12.1) during the period of 


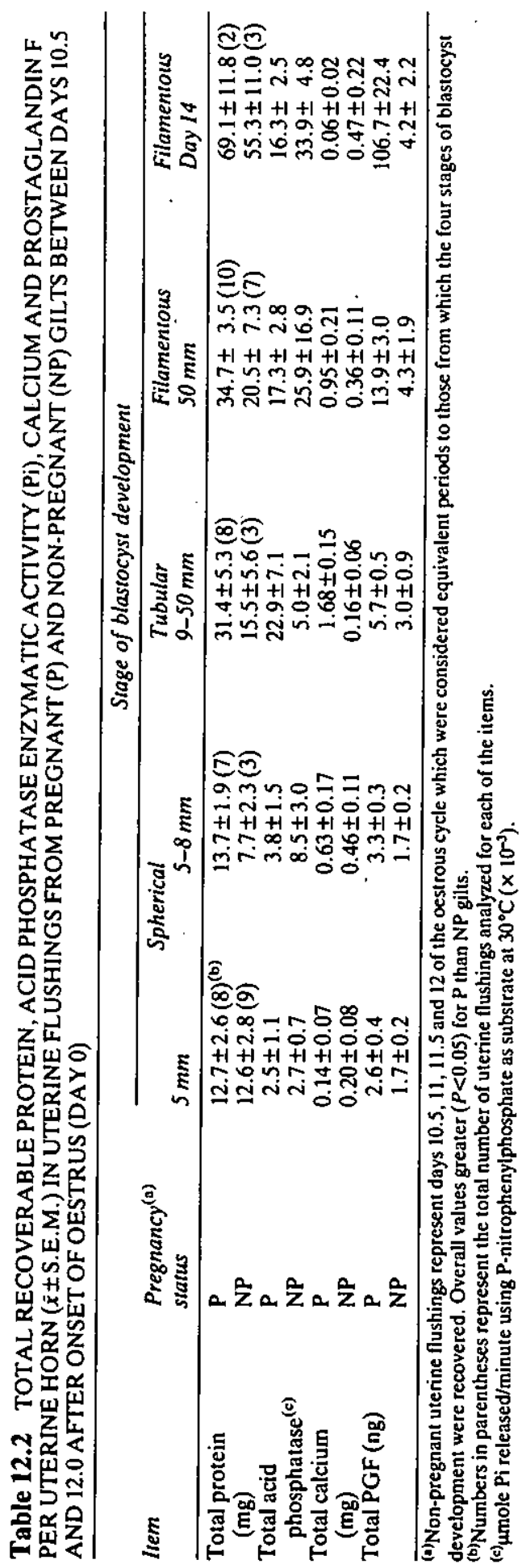


blastocyst elongation have also been analyzed for total recoverable calcium, protein, acid phosphatase (uteroferrin marker) and PGF (Geisert, Bazer, Thatcher and Roberts, unpublished data). Data are summarized for these components in Table 12.2, using the same format as for Table 12.1, since they were also more closely related to stage of blastocyst development than day of pregnancy. Total recoverable calcium, protein and PGF were greater $(P<0.05)$ in uterine flushings from pregnant gilts, but differences in total recoverable acid phosphatase (index for uteroferrin) activity were not significant. The increase in calcium was marked in flushings containing tubular and day 12 filamentous blastocysts as compared with those containing either spherical or day 14 filamentous blastocyśts. Total recoverable protein and PGF increased in a similar pattern except that both of these components continued to increase to day 14 of pregnancy. In comparing Tables 12.1 and 12.2 , temporal events suggest that oestrogens of blastocyst origin may stimulate release of free calcium which would, in turn, induce events which lead to the release of products in secretory vesicles of the uterine epithelium and activate synthesis and secretion of PGF into the uterine lumen. This would result in support for continued blastocyst development and the establishment of pregnancy in the pig.

Events associated with establishment of pregnancy in the pig are similar in many ways to those occurring during the period of termination of embryonic diapause in the roe deer (Aitken, 1979). He reported negligible amounts of protein, carbohydrate, calcium and $\alpha$-amino nitrogen in uterine flushings from roe deer having embryos in diapause, but these increased in association with blastocyst elongation.

Aitken (1974) suggested that secretions accumulate in the apical region of the epithelial cells of uterine glands of roe deer during the period of embryonic diapause which are released to induce and support blastocyst development. The possibility of oestrogens, of blastocyst origin, stimulating this secretory process was also noted by Aitken (1974). Gadsby, Heap and Burton (1980) later demonstrated that elongated roe deer blastocysts can convert androstenedione to oestrone and oestradiol.

\section{Acknowledgements}

Research summarized in this paper has been supported by U.S.D.A. Cooperative Agreement 12-14-7001-1119 and National Institute of Health Grants HD08564 and HD10436.

\section{References}

AITKEN, R.J. (1974). Delayed implantation in roe deer (Capreolus capreolus). J. Reprod. Fert. 39, 225-233

AITKEN, R.J. (1979). The hormonal control of implantation. In Maternal Recognition of Pregnancy, (J. Whelan, Ed.), pp. 53-84. Amsterdam, Excerpta Medica 
AMOROSO, E.C. (1952). Placentation. In Marshall's Physiology of Reproduction, (A.S. Parkes, Ed.), pp. 127-311. Boston, Little, Brown and Co.

ANDERSON, L.L. (1978). Growth, protein content and distribution of early pig embryos. Anat. Rec. 190, 143-154

ANDERSON, L.L. and MELAMPY, R.M. (1967). Hypophysial and uterine influence on pig luteal function. In Reproduction in the Female Mammal, (G.E. Lamming and E.C. Amoroso, Eds), pp. 285-316. New York, Plenum Press

ANDERSON, L.L., BLAND, K.P. and MELAMPY, R.M. (1969). Comparative aspects of uterine-luteal relationships. Recent Prog. Horm. Res. 25, $57-104$

ANDERSON, L.L., BUTCHER, R.L. and MELAMPY, R.M. (1961). Subtotal hysterectomy and ovarian function in gilts. Endocrinology, 69, 571-580

ANDERSON, L.L., LEGLISE, P.C., DU MESNIL DU BUISSON, F. and ROMBAUTS, P. (1965). Interaction des hormones gonadotropes et de l'uterus dans le maintien du tissu luteal ovarien chez la truie. C. r. hebd. Seanc. Acad. Sci., Paris 261, 3675-3678

BARRY, E., HALL, W.J. and MARTIN, J.D.g. (1975). Prostaglandin $E_{1}$ and movement of salt and water in frog skin (Rana temporaria). Gen. Pharmacol. 6, 141-150

BASHA, S.M.M., BAZER, F.W. and ROBERTS, R.M. (1979). The secretion of a uterine-specific, purple phosphatase by cultured explants of porcine endometrium. Dependency upon the state of pregnancy of the donor animal. Biol. Reprod. 20, 431-441

BASHA, S.M.M., BAZER, F.W. and ROBERTS, R.M. (1980). Effect of the conceptus on quantitative and qualitative aspects of uterine secretion in pigs. J. Reprod. Fert. 60, 41-48

BASHA, S.M.M., BAZER, F.W., GEISERT, R.D. and ROBERTS, R.M. (1980). Progesterone-induced uterine secretions in pigs. Recovery from pseudopregnant and unilaterally pregnant gilts. J. Anim. Sci. 50, 113-123

BATTA, S.K. (1975). Effect of prostaglandins on steroid biosynthesis. $J$. Ster. Biochem. 6, 1075-1080

BAZER, F.W. and THATCHER, W.W. (1977). Theory of maternal recognition of pregnancy in swine based on estrogen controlled endocrine versus exocrine secretion of prostaglandin $F_{2 \alpha}$ by the uterine endometrium. Prostaglandins 14, 397-401

BAZER, F.W., ROBERTS, R.M., BASHA, S.M.M., ZAVY, M.T., CATON, D. and BARRON, D.H. (1979). Method for obtaining ovine uterine secretions from unilaterally pregnant ewes. J. Anim. Sci. 49, 1522-1527

BIGGERS, J.D., LEONOV, B.V., BASKAR, J.F. and FRIED, J. (1978). Inhibition of hatching of mouse blastocysts in vitro by prostaglandin antagonists. Biol. Reprod. 19, 519-533

BITO, L.Z. (1972). Comparative study of concentrative prostaglandin accumulation by various tissues of mammals and marine vertebrates and invertebrates. Comp. Biochem. Physiol. 43A, 65-82

BITO, L.Z. and SPELLANE, P.J. (1974). Saturable, 'carrier-mediated', absorption of prostaglandin $F_{2}$ from the in vivo rabbit vagina and its inhibition by prostaglandin $\mathrm{F}_{2}$. Prostaglandins $8,345-352$

BITO, L.Z., WALLENSTEIN, M. and BAROODY, R. (1976). The role of transport 
processes in the distribution and disposition of prostaglandins. Adv. Prostaglandin Thromboxane Res. 1, 297-303

CALDWELL, B.V., MOOR, R.M., WILMUT, I., POLGE, C. and ROWSON, L.E.A. (1969). The relationship between day of formation and functional lifespan of induced corpora lutea in the pig. J. Reprod. Fert. 18, 107-113

CHAKRABORTY, P.K., ENGLAND, D.C. and STORMSHAK, R. (1972). Effect of $17 \beta$-estradiol on pituitary gonadotrophins and luteal function in gilts. $J$. Anim. Sci. 34, 427-429

CHEN, T.T., BAZER, F.W., GEBHARDT, B.M. and ROBERTS, R.M. (1975). Uterine secretion in mammals: Synthesis and placental transport of a purple acid phosphatase in pigs. Biol. Reprod. 13, 304-313

CHOONG, C.H. and RAESIDE, J.I. (1974). Chemical determination of estrogen distribution in the fetus and placenta of the domestic pig. Acta Endocr. 77, 171-185

CHRISTENSON, R.K. and DAY, B.N. (1972). Luteolytic effects of endometrial extracts in the pig. J. Anim. Sci. 34, 620-626

CROMBIE, P.R. (1972). The morphology and ultrastructure of the pig's placenta throughout pregnancy. PhD Dissertation. University of Cambridge

DIEHL, J.R. and DAY, B.N. (1973). Effect of prostaglandin $F_{2 \alpha}$ on luteal function in swine. J. Anim. Sci. 37, 307 (Abstract)

DIEHL, J.R. and DAY, B.N. (1974). Effect of prostaglandin $F_{2 \alpha}$ on luteal function in swine. J. Anim. Sci. 39, 392-396

DOUGLAS, R.H. and GINTHER, O.J. (1975). Effect of prostaglandin $F_{2 \alpha}$ on estrous cycles or corpus luteum in mares and gilts. J. Anim. Sci. 40, 518-522

DUEBEN, B.D., WISE, T.H., BAZER, F.W. and FIELDS, M.J. (1977). Metabolism of $\mathrm{H}^{3}$-progesterone to androgens by pregnant gilt endometrium. Proc. Am. Soc. Anim. Sci., Madison, Wisconsin, p. 153

DUEBEN, B.D., WISE, T.H., BAZER, F.W., FIELDS, M.J. and KALRA, P.S. (1979). Metabolism of $\mathrm{H}^{3}$-progesterone to estrogens by pregnant gilt endometrium and conceptus. Proc. Am. Soc. Anim.Sci., Tuscon, Arizona, p. 263

DU MESNIL DU BUISSON, F. (1966). Contribution a l'etude du maintien du corps jaune de la truie. PhD Dissertation. Institut National de la Recherche Agronomique, Nouzilly, France

DU MESNIL DU BUISSON, F. and DAUZIER, L. (1959). Controle mutuel de l'uterus et de l'ovarie chez la truie. Annls Zootech., Serie D, Suppl. 149-151

DU MESNIL DU BUISSON, F. and LEGLISE, P.C. (1963). Effet de l'hypophysectomie sur les corps jaunes de la truie. Résultats préliminaires. C.r. hebd. Seanc. Acad. Sci., Paris 257, 261-263

ELEY, R.M., THATCHER, W.W. and BAZER, F.W. (1979). Hormonal and physical changes associated with bovine conceptus development. $J$. Reprod. Fert. 55, 181-190

FLINT, A.P.F., BURTON, R.D., GADSBY, J.E., SAUNDERS, P.T.K. and HEAP, R.B. (1979). Blastocyst oestrogen synthesis and the maternal recognition of pregnancy. In Maternal Recognition of Pregnancy, (J. Whelan, Ed.), pp. 209-238. Amsterdam, Excerpta Medica

FORD, S.P., and CHRISTENSON, R.K. (1979). Blood flow to uteri of sows 
during the estrous cycle and early pregnancy: Local effect of the conceptus on the uterine blood supply. Biol. Reprod. 21, 617-624

FRANK, M., BAZER, F.W., THATCHER, W.W. and WILCOX, C.J. (1977). A study of prostaglandin $F_{2 \alpha}$ as the luteolysin in swine: III. Effects of estradiol valerate on prostaglandin $F$, progestins, estrone, and estradiol concentrations in the utero-ovarian vein of nonpregnant gilts. Prostaglandins 14, 1183-1196

FRANK, M., BAZER, F.W., THATCHER, W.W. and WILCOX, C.J. (1978). A study of prostaglandin $F_{2 \alpha}$ as the luteolysin in swine: IV. An explanation for the luteotrophic effect of estradiol. Prostaglandins 15, 151-160

GADSBY, J.E., HEAP, R.B. and BURTON, R.D. (1980). Oestrogen production by blastocyst and early embryonic tissue of various species. J. Reprod. Fert. 60, 409-417

GARDNER, M.L., FIRST, N.L. and CASIDA, L.E. (1963). Effect of exogenous estrogens on corpus luteum maintenance in gilts. J. Anim. Sci. 22, 132-134

GLEESON, A.R., THORBURN, G.D. and COX, R.I. (1974). Prostaglandin F concentrations in the utero-ovarian vein plasma of the sow during the late luteal phase of the estrous cycle. Prostaglandins 5, 521-530

GOLDSTEIN, M.H., BAZER, F.W. and BARRON, D.H. (1980). Characterization of changes in volume, osmolarity and electrolyte composition of porcine fetal fluids during gestation. Biol. Reprod. 22, 1168-1180

GUTHRIE, H.D. and REXROAD, C.E., Jr. (1980). Progesterone secretion and prostaglandin $F$ release in vitro by endometrial and luteal tissue of cyclic pigs. J. Reprod. Fert. 60, 157-163

GUTHRIE, H.D., HENRICKS, D.M. and HANDLIN, D.L. (1972). Plasma estrogen, progesterone and luteinizing hormone prior to estrus and during early pregnancy in pigs. Endocrinology 91, 675-679

GUTHRIE, H.D., REXROAD, C.E., Jr and BOLT, D.J. (1978). In vitro synthesis of progesterone and prostaglandin $F$ by luteal tissue and prostaglandin $F$ by endometrial tissue from the pig. Prostaglandins 16, 433-440

HALLFORD, D.M. WETTEMANN, R.P., TURMAN, E.J. and OMTVEDT, I.T. (1974). Luteal function in gilts after prostaglandin $\mathrm{F}_{2 \alpha}$.J. Anim. Sci. 28, 213 (Abstract)

HARRISON, F.A., HEAP, R.B. and POYSER, N.L. (1976). Production, chemical composition and prostaglandin $F_{2 \alpha}$ content of uterine fluid in pregnant sheep. J. Reprod. Fert. 48, 61-67

HARRISON, F.A., HEAP, R.B., HORTON, E.W. and POYSER, N.L. (1972). Identification of prostaglandin $F_{2 \alpha}$ in uterine fluid from the non-pregnant sheep with an autotransplanted ovary. J. Endocr. 53, 215-222

HEAP, R.B. and PERRY, J.S. (1974). The maternal recognition of pregnancy. Br. J. Hosp. Med. 12, 8-14

HEAP, R.B., FLINT, A.P.F., GADSBY, J.E. and RICE, C. (1979). Hormones, the early embryo and the uterine environment. J. Reprod. Fert. 55, 267-275

HEINTZE, K., LEINESSER, W., PETERSEN, K.U. and HEIDENREICH, O. (1975). Triphasic effect of prostaglandins $E_{1}, E_{2}$ and $F_{2}$ on the fluid transport of isolated gall-bladder of guinea-pigs. Prostaglandins 9, 309-322

HENDERSON, K.M. and McNATTY, K.P. (1975). A biochemical hypothesis to explain the mechanism of luteal regression. Prostaglandins 9, 779-797 
HENRICKS, D.M. and TINDALL, D.J. (1971). Metabolism of progesterone-4$C^{14}$ in porcine uterine endometrium. Endocrinology 89, 920-924

JANSON, P.O., ALBRECHT, I. and AHREN, K. (1975). Effects of prostaglandin $\mathrm{F}_{2 \alpha}$ on ovarian blood flow and vascular resistance in the pseudopregnant rabbit. Acta Endocr. 79, 337-350

KENNEDY, T.G. (1980). Estrogen and uterine sensitization for the decidual cell reaction: Role of prostaglandins. Biol. Reprod. 23, 955-962

KIDDER, H.E., CASIDA, L.E. and GRUMMER, R.H. (1955). Some effects of estrogen injections on estrual cycle of gilts. J. Anim. Sci. 14, 470-474

KILLIAN, D.B., DAVIS, D.L. and DAY, B.N. (1976). Plasma PGF and hormonal changes during the estrous cycle and early pregnancy in the gilt. Proc. Int. Pig Vet. Soc., Ames, Iowa, pp. D.1

KNIGHT, J.W., BAZER, F.W., THATCHER, W.W., FRANKE, D.E. and WALLACE, H.D. (1977). Conceptus development in intact and unilaterally hysterectomized-ovariecomized gilts: Interrelations between hormonal status, placental development, fetal fluids and fetal growth. J. Anim. Sci. 44, 620-637

KRAELING, R.R., BARB, C.R. and DAVIS, B.J. (1975). Prostaglandin induced regression of porcine corpora lutea maintained by estrogen. Prostaglandins 9, 459-462

KRZYMOWSKI, T., KOTWICA, J., OKRASA, S. and DOBOSZYNSKA, T. (1976). The function and regression of corpora lutea during the sow's estrous cycle after 10 hours of prostaglandin $\mathrm{F}_{2 \alpha}$ infusion into the anterior uterine vein. Proc. VIII Int. Congr. Anim. Reprod. A. I., Krakow, p. 143

LaMOTTE, J.O. (1977). Prostaglandins: I. Presence of a prostaglandin-like substance in porcine uterine flushings; II. A new chemical assay for $\mathrm{PGF}_{2}$ alpha. Anim. Breed. Abstr. 45, 572

LEWIS, G.S., THATCHER, W.W., BAZER, F.W., ROBERTS, R.M. and WILLIAMS, W.F. (1979). Metabolism of arachidonic acid by bovine blastocysts and endometrium. Proc. Am. Soc. Anim. Sci. Tuscon, Arizona, pp. 313-334

LOEB. L. (1923). The effect of extirpation of the uterus on the life and function of the corpus luteum in the guinea pig. Proc. Soc. exp. Biol. Med. 20, 441-464

MacMANUS, J.P. and WHITFIELD, J.F. (1974). Cyclic AMP, prostaglandins and the control of cell proliferation. Prostaglandins 6, 475-487

MOELJONO, M.P.E., BAZER, F.W. and THATCHER, W.W. (1976). A study of prostaglandin $F_{2 \alpha}$ as the luteolysin in swine: I. Effect of prostaglandin $\mathrm{F}_{2 \alpha}$ in hysterectomized gilts. Prostaglandins 11, 737-743

MOELJONO, M.P.E. THATCHER, W.W., BAZER, F.W., FRANK, M., OWENS, L.J. and WILCOX, C.J. (1977). A study of prostaglandin $F_{2 \alpha}$ as the luteolysin in swine: II. Characterization and comparison of prostaglandin $F$, estrogen and progestin concentrations in utero-ovarian vein plasma of nonpregnant gilts. Prostaglandins 14, 543-555

MOLOKWU, E.C. and WAGNER, W.C. (1973). Endocrine physiology of the puerperal sow. J. Anim. Sci. 36, 1158-1163

OGRA, S.S., KIRTON, K.T., TOMASI, T.B. and LIPPES, J. (1974). Prostaglandins in the human fallopian tube. Fert. Steril. 25, 250-255

PATEK, C.E. and WATSON, J. (1976). Prostaglandin F and progesterone secretion by porcine endometrium and corpus luteum in vitro. Prostaglandins 12, 97-111 
PERRY, J.S. and ROWLANDS, I.W. (1962). Early pregnancy in the pig. $J$. Reprod. Fert. 4, 175-188

PERRY, J.S., HEAP, R.B. and AMOROSO, E.C. (1973). Steroid hormone production by pig blastocysts. Nature, Lond. 245, 45-47

PERRY, J.S., HEAP, R.B., BURTON, R.D. and GADSBY, J.E. (1976). Endocrinology of the blastocyst and its role in the establishment of pregnancy. $J$. Reprod. Fert. Suppl. 25, 85-104

PHARRIS, B.B. and WYNGARDEN, I.J. (1969). The effect of prostaglandin $F_{2 \alpha}$ on the progesterone content of ovaries from pseudopregnant rats. Proc. Soc. exp. Biol. Med. 130, 92-94

RAESIDE, J.I. (1963). Urinary estrogen excretion in the pig during pregnancy and parturition. J. Reprod. Fert. 6, 427-431

ROBERTS, R.M. and BAZER, F.W. (1980). The properties, function and hormonal control of synthesis of uteroferrin, the purple protein of the pig uterus. In Steroid Induced Uterine Proteins, (M. Beato, Ed.), pp. 133-149. Amsterdam, Elsevier/North Holland Biomedical Press

ROBERTSON, H.A. and KING, G.J. (1974). Plasma concentrations of progesterone, estrone, estradiol- $17 \beta$ and estrone sulphate in the pig at implantation, during pregnancy and at parturition. J. Reprod. Fert. 40, 133-141

SCHLAFKE, S. and ENDERS, A.C. (1975). Cellular basis of interaction between trophoblast and uterus at implantation. Biol. Reprod. 12, 41-65

SCHOMBERG, D.W. (1967). A demonstration in vitro of luteolytic activity in pig uterine flushings. $J$. Endocr. 38, 359-360

SCHOMBERG, D.W. (1969). The concept of a uterine luteolytic hormone. In The Gonads, (K.W. McKerns, Ed.), pp. 282-397. New York, AppletonCentury-Croft

SHILLE, V.M., KARLBOM, I., EINARSSON, S., LARSSON, K. KINDAHL, H. and EDQVIST, L.E. (1979). Concentrations of progesterone and 15-keto13,14-dihydroprostaglandin $F_{2 \alpha}$ in peripheral plasma during the estrous cycle and early pregnancy in gilts. Zentbl. VetMed. 26, 169-181

SPIES, H.G., ZIMMERMAN, D.R., SELF, H.L. and CASIDA, L.E. (1958). Influence of hysterectomy and exogenous progesterone on size and progesterone content of the corpora lutea in gilts. J. Anim. Sci. 17, 1234 (Abstract)

TERQUI, M., MARTINAT-BOTTE, F. and THATCHER, W.W. (1979). Early diagnosis of pregnancy in sows: Determination of $\mathrm{PGF}_{2 \alpha}$ levels on the 14th and 15 th days after insemination. Journées de la recherche porcine en France, pp. 365-371. Paris, L'Institut Technique du Porc

THATCHER, W.W. and CHENAULT, J.R. (1976). Reproductive physiological responses of cattle to exogenous prostaglandin $\mathrm{F}_{2 \alpha}$.J. Dairy Sci. 59, 1366-1375

THATCHER, W.W., WILCOX, C.J., BAZER, F.W., COLLIER, R.J., ELEY, R.M. STOVER, D.G. and BARTOL, F.F. (1979). Bovine conceptus effects prepartum and potential carryover effects postpartum. In Animal Reproduction 3, Beltsville Symposia in Agriculture Research, (H.H. Hawk, Ed.), pp. 259-275. New Jersey, Osmum and Company

VELLE, W.(1960). Early pregnancy diagnosis in the sow.Vet.Rec.72,116-118 WALKER, F.M.M. PATEK, C.E., LEAF, C.F. and WATSON, J. (1977). The metabolism of prostaglandins $F_{2 \alpha}$ and $E_{2}$ by nonpregnant porcine endometrial tissue, luteal tissue and conceptuses in vitro. Prostaglandins 14, 557-562 
WATSON, J. and PATEK, C.E. (1979). Steroid and prostaglandin secretion by the corpus luteum, endometrium and embryos of cyclic and pregnant gilts. J. Endocr. 82, 425-428

WATSON, J. and WALKER, F.M.M. (1977). Effect of prostaglandin $F_{2 \alpha}$ and uterine extracts on progesterone secretion in vitro by superfused pig corpora lutea. J. Reprod. Fert. 51, 393-398

WETTEMANN, R.P., HALLFORD, D.M., KREIDER, D.L. and TURMAN, E.J. (1977). Influence of prostaglandin $F_{2 \alpha}$ on endocrine changes at parturition in gilts. J. Anim. Sci. 44, 107-111

WILSON, J.D. (1972). Recent studies on the mechanism of action of testosterone. New Engl. J. Med. 287, 1284-1291

ZAVY, M.T. (1979). A comparison of the nonpregnant and pregnant uterine luminal environments in the porcine and equine. PhD Dissertation. University of Florida

ZAVY, M.T., BAZER, F.W., THATCHER, W.W. and WILCOX, C.J. (1980). A study of prostaglandin $F_{2 \alpha}$ as the luteolysin in swine: V. Comparison of prostaglandin $F$, progestins, estrone and estradiol in uterine flushings from pregnant and nonpregnant gilts. Prostaglandins 20, 837-851 